\title{
Vegetational Analysis, Carbon Stock and Regeneration Potential of Myrica esculenta at Different Forest Sites around Nainital
}

\author{
PRATIBHA GWAL, NEELU LODHIYAL, Y. S. RAWAT and BHAWNA ADHIKARI
}

Department of Botany, D.S.B. Campus, Kumaun University, Nainital- 263002, India.

http://dx.doi.org/10.12944/CWE.11.3.13

(Received: August 25, 2016; Accepted: October 27, 2016)

\begin{abstract}
The present study deals with the assessment of species diversity, regeneration potential and carbon stock of Myrica esculenta (Buch.-Ham. ex D. Don) trees at different forest sites around Nainital. The density of trees, saplings and seedlings across different forests varied from $660-860$, 460-1410 and 1480-3130 ind.ha- ${ }^{-1}$. The species diversity ranged from 1.979-2.322, 1.525-2.024 and $1.689-2.142$, for trees, saplings and seedlings, respectively. Among forests, the regeneration was best in Cypress mixed forest. Thus, the presence of either seedlings or saplings of new tree species in the forest site 1 and 2 indicate that the forest may be replaced by these species in near future. Total trees biomass of forests ranged from 213-349 $\mathrm{t} \mathrm{ha}^{-1}$. Of this, M. esculenta accounted for $9-24 \%$. Total carbon content of trees in forests ranged from 101-166 t C ha-1. M. esculenta (Kaphal) fruits are edible and trees are destroyed for fuel wood by local people, therefore, Kaphal trees are under high anthropogenic pressure. Thus we need to pay attention and take proper care for management and conservation of forest sites with Kaphal trees.
\end{abstract}

Keywords: Myrica esculenta; saplings; seedlings; regeneration; density; species diversity; biomass; carbon content.

\section{INTRODUCTION}

Himalaya is known as an abode of wild edible plants. Myrica esculenta Buch.-Ham. ex D. Don is sub temperate evergreen tree found throughout the mid-Himalaya, starting from about $1,300 \mathrm{~m}$ altitude and going up to about 2,100 m. M. esculenta belongs to family Myricaceae. Vernacular name of Myrica is Kaphal. M. esculenta is evergreen tree found in pine zone and lowest part of oak zone. In the Western Himalaya, the species occurs mainly in Pinus roxburghii forest, Quercus leucotrichophora forest and mixed-Oak forest and is widely accepted among local people for its delicious fruits and processed products $^{1,2}$. Fruits are edible and delicious and trees are also used for fuel and fodder purpose by local people. The M. esculenta have many medicinal values. The aqueous extract of $M$. esculenta has potent wound healing capacity as evident from the wound contraction and increased tensile strength, beside antioxidant activity to understand the mechanism of wound healing activity. The report of the efficacy of this plant as wound healing may be due to its action against dermatophyte which in turn can also be correlated to the effect on antioxidant enzymes ${ }^{3}$. M. esculenta is a dioecious fruit tree and female trees are economically preferred much more than the male ones.

Anthropogenic activities affect biodiversity, both directly and indirectly through land use and resource utilization. Such changes have a direct impact through habitat destruction and over exploitation of resources such as overgrazing and harvest of biomass, and indirect impact through their effect on the composition of the atmosphere and 
climate. The conservation of biological resources under community based conservation system is a key tool to lessen the depletion of biodiversity, otherwise the regular extraction pressure on important usable plant species in hilly areas is negatively impacting ${ }^{4}$. In recent years, pressure on M. esculenta have increased due to rapid increase of land value, the developmental practices, channelling streams, building roads and cities in forest area. Chronic disturbance in these forests particularly is a common practice lopping of trees for fuel wood and leaf fodder. Hence, these forests are under high lopping pressure particularly on vicinity of the human settlement ${ }^{5}$.

\section{MATERIALS AND METHODS}

\section{Study area}

The study was conducted in three forest sites around Nainital at Monera village. The present study area Nainital is located between $29^{\circ} 21^{\prime}$ to $29^{\circ} 24^{\prime} \mathrm{N}$ latitude and $79^{\circ} 25^{\prime}$ to $79^{\circ} 29^{\prime} \mathrm{E}$ longitude. The study sites are located between 1991-2200 $\mathrm{m}$ altitudes. The sites are moderately to relatively disturbed. Site-1 is dominated by Cupressus torulosa, site- 2 by Cedrus deodara and site- 3 by
Quercus leucotrichophora. The soil is coarse and sandy loam and rich in nutrients. The soil is acidic in nature at all forest sites.

\section{METHODS}

The vegetation analysis of plants was done by using quadrats of $10 \times 10 \mathrm{~m}$ size. The sampling size and number of quadrats were determined following ${ }^{6}$. In each quadrat trees were sampled. Individuals with above $31 \mathrm{~cm}$ cbh (circumference at breast height, i.e. $1.37 \mathrm{~m}$. from the ground) were considered trees, saplings with $10-30 \mathrm{~cm}$ cbh and seedlings $>$ less than $10 \mathrm{~cm}$ cbh were grouped and considered for different category. The vegetation analysis was done by using the quadrat method ${ }^{7}$. Species diversity $\left(\mathrm{H}^{\prime}\right)$ for each vegetation layer was calculated by using ShannonWeiner information index ${ }^{8}$.

$$
\mathrm{H}^{\prime}=\Sigma \mathrm{Ni} / \mathrm{N} \times 3.322 \times \log \mathrm{Ni} / \mathrm{N}
$$

Where, $\mathrm{H}^{\prime}=$ species diversity, $\mathrm{Ni}=$ total number of individuals of a species and $\mathrm{N}$ is total number of individuals of all tree species.

Concentration of dominance (Cd) was measured by Simpsons Index ${ }^{9}$.

Table 1: Density (ind.ha-1) of trees (T), saplings (Sap) and seedlings (S) of different tree species in each forest site. Values in parenthesis are \% contribution of $M$. esculenta in density

\begin{tabular}{lccccccccc}
\hline \multirow{2}{*}{ Species } & \multicolumn{3}{c}{ Cypress forest } & \multicolumn{3}{c}{ Deodar forest } & \multicolumn{3}{c}{ Oak-Myrica Forest } \\
& Tree & Sap & S & Tree & Sap & S & Tree & Sap & S \\
\hline Cupressus torulosa & 430 & - & - & 40 & - & 20 & 160 & 30 & - \\
Quercus leucotrichophora & 90 & 10 & 930 & 50 & 20 & 680 & 160 & 200 & 780 \\
Myrica esculenta & 120 & 570 & 450 & 80 & 270 & 50 & 340 & 650 & 130 \\
& $(15.4)$ & $(72.2)$ & $(14.4)$ & $(12.1)$ & $(58.7)$ & $(3.4)$ & $(39.6)$ & $(46.1)$ & $(8.6)$ \\
Rhododendron arboreum & 60 & - & 100 & 60 & - & 10 & 60 & 90 & 120 \\
Lyonia ovalifolia & 60 & 170 & 1340 & 30 & 110 & 610 & 90 & 360 & 330 \\
Cedrus deodara & 10 & - & - & 380 & 60 & 40 & - & - & - \\
Aesculus indica & - & 10 & 150 & - & - & - & - & - & 80 \\
Fraxinus micrantha & - & 20 & 30 & - & - & - & - & - & - \\
Symplocos chinensis & - & 10 & 40 & - & - & - & - & - & - \\
Pinus roxburghii & 10 & - & 10 & 20 & - & 70 & - & - & - \\
Coriaria napalensis & - & - & - & - & - & - & 40 & 80 & - \\
Ficus numoralis & - & - & - & - & - & - & 10 & - & - \\
Thuja orientalis & - & - & 60 & - & - & - & - & - & - \\
Pyrus pashia & - & - & 20 & - & - & - & - & - & 70 \\
Total & 780 & 790 & 3130 & 660 & 460 & 1480 & 860 & 1410 & 1510 \\
\hline
\end{tabular}


$\mathrm{Cd}=(\mathrm{Ni} / \mathrm{N})^{2}$

Where, $\mathrm{Cd}=$ concentration dominance, $\mathrm{Ni}=$ total number of individuals of tree species and $\mathrm{N}=$ total number of individuals of all tree species.

For assessment of population structure, the following size classes were used based on available field data i.e. (1) seedlings $(<10 \mathrm{~cm}),(2)$ saplings (10$30 \mathrm{~cm})$ and $(3)$ trees $(>30 \mathrm{~cm})$. Regeneration status of tree species was assessed by following Shankar ${ }^{10}$.

\section{Biomass storage and carbon stock of trees}

Biomass of different component of trees was estimated by using linear regression equations already developed ${ }^{11,12}$ for different oak and associated tree species of Himalayas. Carbon stock $(C=$ Biomass $\times 0.475)$ was estimated as $50 \%$ of the dry weight ${ }^{13}$.

\section{RESULTS}

In Cypress forest site, a total of 12 tree species were reported. Total tree density was 780 ind.ha ${ }^{-1}$, of which M. esculenta showed 120 ind.ha $^{-1}$ (15.38\%). The saplings density was 790 ind.ha ${ }^{-1}$. M. esculenta showed maximum density of saplings i.e. 570 ind. $^{-1}(72.15 \%)$. Total density of seedlings was 3130 ind.ha-1 ${ }^{-1}$, of which M. esculenta showed $14.4 \%$ density of seedlings (450 ind.ha-1) (Table 1). The species diversity and concentration of dominance of trees, saplings, and seedlings was 1.979, 1.19, 2.142 and $0.353,0.568,1$, respectively in Cypress forest site (Table 2).

In Deodar forest site, a total of 7 tree species were reported. Total tree density was 660 ind.ha ${ }^{-1}$, of which $M$. esculenta showed 80 ind.ha $^{-1}$ $(12.12 \%)$ of trees. The density of saplings was 460 ind.ha ${ }^{-1}$. M. esculenta showed maximum density of saplings i.e. 270 ind.ha $^{-1}(58.69 \%)$. Total density of seedlings was 1480 ind.ha $^{-1}$, of which $M$. esculenta showed $3.37 \%$ density of seedlings (50 ind.ha- ${ }^{-1}$ ) (Table 1). The species diversity and concentration of dominance of trees, saplings, and seedlings was $2.025,1.525,1.689$ and 0.366, 0.42, 0.385, respectively in Deodar forest site (Table 2 ).

In Oak- Myrica forest site, a total of 9 tree species were reported. Total tree density was 860 ind.ha ${ }^{-1}$, of which M. esculenta showed 340 ind.ha $^{-1}$ (39.53\%). The density of saplings was 1410 ind.ha ${ }^{-1}$. $M$. esculenta showed maximum density of saplings i.e. 650 ind. $^{-1}$ (46.09\%). Total seedlings density was 1510 ind.ha $^{-1}$, of which M. esculenta showed $8.60 \%$ density of seedlings (130 ind.ha-1) (Table 1). The species diversity and concentration of dominance of trees, saplings, and seedlings was 2.322, 2.024, 1.997 and $0.244,0.305,0.333$, respectively in OakMyrica forest site (Table 2).

Table 2: Diversity $\left(\mathrm{H}^{\prime}\right)$ and concentration of dominance

(Cd) of trees, saplings and seedlings at each forest site

\begin{tabular}{llccccc}
\hline Tree layer & \multicolumn{2}{c}{ Cypress forest } & \multicolumn{2}{c}{ Deodar forest } & \multicolumn{2}{c}{ Oak-Myrica forest } \\
& $\mathbf{H}^{\prime}$ & $\mathbf{C d}$ & $\mathbf{H}^{\prime}$ & $\mathbf{C d}$ & $\mathbf{H}^{\prime}$ & $\mathbf{C d}$ \\
\hline Trees & 1.979 & 0.353 & 2.025 & 0.366 & 2.322 & 0.244 \\
Saplings & 1.190 & 0.568 & 1.525 & 0.420 & 2.024 & 0.305 \\
Seedlings & 2.142 & 1.000 & 1.689 & 0.385 & 1.997 & 0.333 \\
\hline
\end{tabular}

Table 3: Total biomass and Carbon stock of trees in each forest site. Values in parenthesis are \% contribution of $M$. esculenta in biomass and carbon content

\begin{tabular}{lcccc}
\hline Forests sites & $\begin{array}{c}\text { Biomass } \\
\left(\mathbf{t ~ h a}^{-1}\right)\end{array}$ & $\begin{array}{c}\text { Carbon } \\
\left(\mathbf{t ~ C ~ h a - 1}^{-1}\right)\end{array}$ & $\begin{array}{c}\text { Biomass (t ha-1) of } \\
\text { M. esculenta }\end{array}$ & $\begin{array}{c}\text { Carbon (t C ha-1) } \\
\text { of } \text { M. esculenta }\end{array}$ \\
\hline Cypress forest & 309.21 & 145.76 & $30.70(9.93)$ & $14.58(10)$ \\
Deodar forest & 213.13 & 101.23 & $24.75(11.61)$ & $11.76(11.61)$ \\
Oak- Myrica forest & 349.33 & 166.01 & $84.69(24.24)$ & $40.24(24.23)$ \\
\hline
\end{tabular}




\section{Biomass and carbon content}

In Cypress forest site, total biomass and carbon content of tree species was 309.21 and $145.76 \mathrm{t} \mathrm{ha}^{-1}$, respectively, of which $M$. esculenta showed $30.70 \mathrm{t} \mathrm{ha}^{-1}(9.93 \%)$ and $14.58 \mathrm{t} \mathrm{ha}^{-1}(10 \%)$ biomass and carbon, respectively (Table 3 ).

In Deodar forest site, total biomass and carbon content of tree species was 213.13 and $101.23 \mathrm{t} \mathrm{ha}^{-1}$, respectively, of which $M$. esculenta showed $24.75 \mathrm{t} \mathrm{ha}^{-1}(11.61 \%)$ and 11.76 $t^{t}$ ha $^{-1}(11.76 \%)$ biomass and carbon, respectively (Table 3).
In Oak- Myrica forest site, total biomass and carbon content of tree species was 349.33 and $166.01 \mathrm{t} \mathrm{ha}^{-1}$, respectively of which $M$. esculenta showed $80.69 \mathrm{t} \mathrm{ha}^{-1}(24.24 \%)$ and $40.24 \mathrm{t} \mathrm{ha}^{-1}$ (24.23\%) biomass and carbon, respectively (Table 3).

\section{Population structure and Regeneration status}

The overall regeneration status of tree species at Cypress forest site indicated good regeneration with higher number of seedlings as compared to saplings and adult trees (Fig. 1). $M$. esculenta showed good regeneration in past with higher number of saplings as compared to seedlings and adult trees (Fig. 2). The overall regeneration

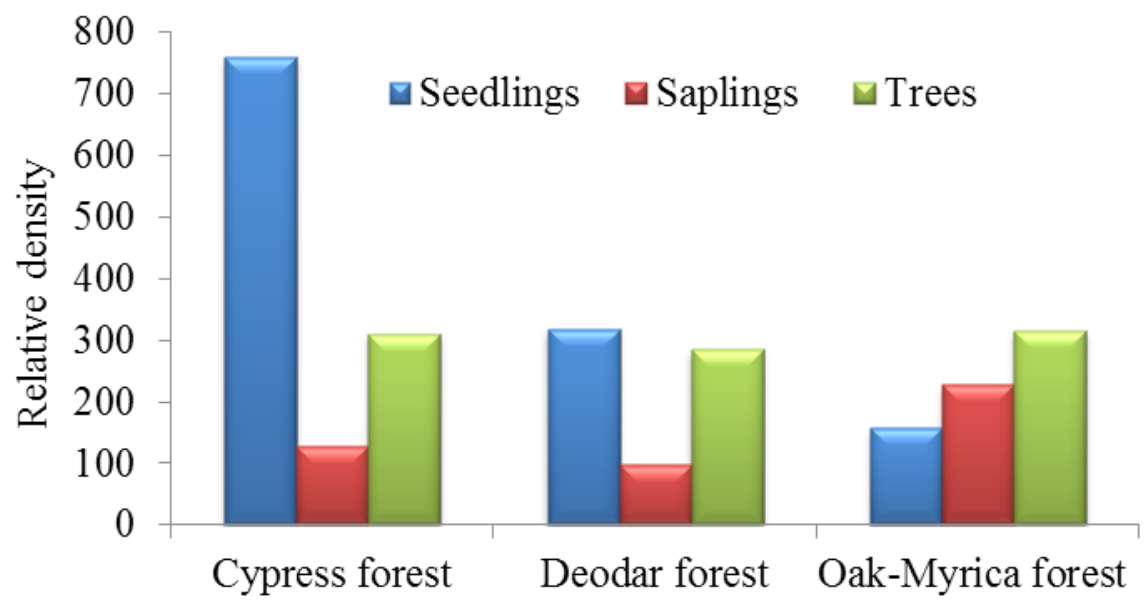

Fig. 1: Population structure of tree species across different forests sites

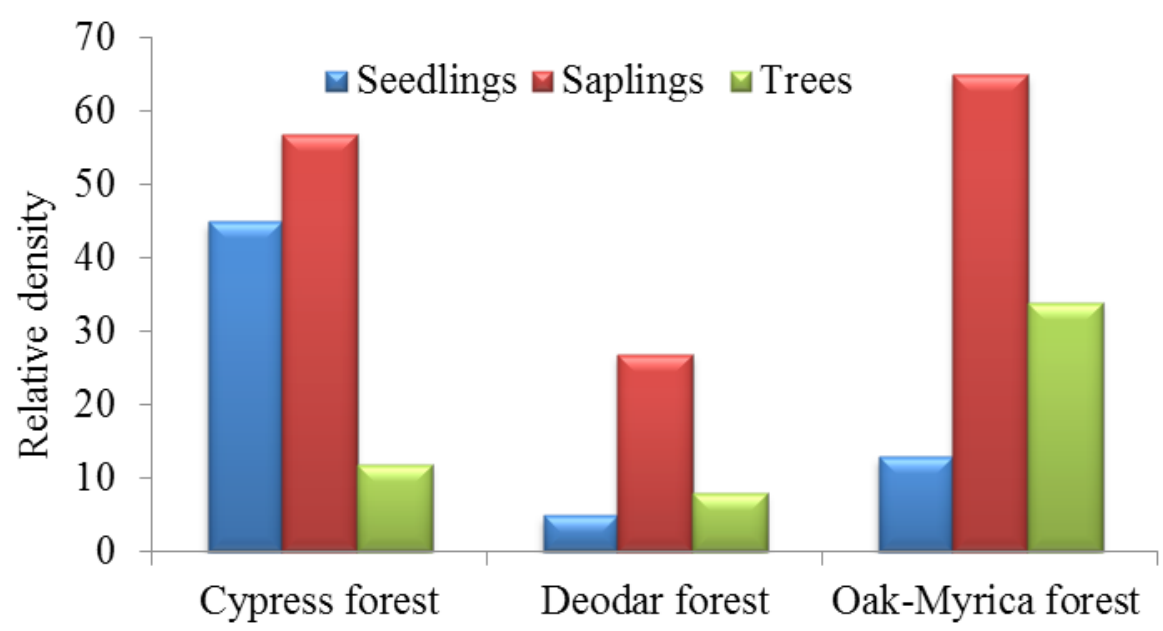

Fig. 2: Population structure of $M$. esculenta at different forest sites 
status of tree species at Deodar forest site showed fair regeneration with higher number of seedlings and adult trees than saplings (Fig. 1). M. esculenta showed good regeneration in past with higher number of saplings as compared to seedlings and adult trees (Fig. 2). The overall regeneration status of tree species at Oak-Myrica forest site showed poor regeneration with higher number of trees as compared to saplings and seedlings (Fig. 1). $M$. esculenta showed good regeneration in past with higher number of saplings as compared to seedlings and adult trees (Fig. 2).

\section{DISCUSSION}

The density of tree species ranged from 660-860 ind.ha-1 across different sites. Present values are comparable with that (760 ind.ha-1) reported for Oak forests ${ }^{11}$, and are higher than that (349 ind.ha-1) reported for Western Himalayan forests ${ }^{14}$. The density value 930 ind.ha $^{-1}$ was reported for $Q$. floribunda forest ${ }^{15}$. The values are higher than those reported for disturbed Oak forest (490-640 ind. $\left.\mathrm{ha}^{-1}\right)$ and are comparable with the values reported for undisturbed Oak forests (630-920 ind.ha-1) of Nainital ${ }^{16}$. However, present estimates are low than those (1330 ind.ha ${ }^{-1}$ ) reported for oak and pine mixed forest ${ }^{17}$. The values falls within range $300-960$ ind. ha $^{-1}$ reported for dominant tree species of Nainital in Kumaun Himalaya ${ }^{18}$.

Density of saplings in the present study ranged from 460-1410 ind.ha-1. These values are comparable with those (760 ind.ha-1) reported for Oak forests by ${ }^{10}$. The saplings density values are less than (2061 ind.ha-1) those reported for $Q$. floribunda forest at Government House, Nainital ${ }^{14}$ and falls within the range 788-1718 ind.ha ${ }^{-1}$ reported for Central Himalayan forests ${ }^{19}$.

The density of seedlings in the present study was 1480-3130 ind.ha-1 (Table 1). The values are higher than those reported for Oak forests (2030 ind.ha $\left.{ }^{-1}\right)^{11}$ and are less than those reported for $Q$. floribunda forests (10899 ind.ha $\left.{ }^{-1}\right)^{14}$ and for $Q$. floribunda forest in Government House, Nainital ${ }^{20}$.

Species diversity of trees ranged from 1.97-2.32 which fall within the range reported $(0.46$ -2.02) for Oak forest in Nainital district of Kumaun
Himalayas ${ }^{19}$. 1.2-2.7 for Central Himalayan forest ${ }^{15}$ and $0.78-3.45$ for Garhwal Himalaya ${ }^{21}$. The mixed forest had the greatest tree diversity and the diversity increased with increasing basal cover ${ }^{6}$.

Good and Good ${ }^{22}$ have considered three major components which cause the successful regeneration of tree species. These components are (i) the ability to initiate new seedlings, (ii) ability of seedlings and saplings to survive and (iii) ability of seedlings and saplings to grow ${ }^{23}$. As indicated by population structures, Myrica esculenta (Buch-Ham. ex D. Don) has immense capacity of nitrogen fixation and therefore, will flourish at different forest sites near future. Myrica esculenta is a nitrogen fixer tree species and provide edible fruits in summer season and give lots of revenue to local people at Nainital which is a tourist place and its good regeneration would certainly enhance soil fertility at forest sites. It had been used in the traditional healthcare system from time immemorial, particularly by the local and indigenous communities ${ }^{24}$.

Sufficient number of seedlings of $Q$. leucotrichophora were reported at all study sites. Surprisingly, saplings were almost absent at site-1 and site-2, while a few saplings were reported at study site-3. Cedrus deodara was also represented by only old trees. It is evident that these forests may be replaced by Myrica esculenta and Fraxinus micrantha in near future. The symbiotic nitrogen fixing ability of both Myrica esculenta and Coriaria nepalensis at site-3 may play a very important role in improving soil and habitat quality. As indicated by population structures, there are chances of replacement of tree species at site-1 and site-2 by Pinus roxburghii, which will create shortage of nutrients in soil. P. roxburghii will replace Himalayan Oak forests in near future at site-1 and site-2. $C$. torulosa which is the dominant tree species at site-1 showed no regeneration at site-1. C. deodara showed poor regeneration at site -2 . Q. leucotrichophora showed good regeneration at site-3 which indicates pressure on species for fuel and fodder. Presence of seedlings of $A$. indica, and F. micrantha at all sites predict the change in species composition in near future. Once replaced by Chir-pine, Oak will not be able to establish again and the soil will be converted from eutrophic (nutrient rich) to oligotrophic (nutrient poor) condition. 


\section{ACKNOWLEDGEMENTS}

Authors are thankful to Department of Botany, D.S.B. Campus, Kumaun University, Nainital for providing necessary facilities.

\section{REFERENCES}

1. Dhyani, P.P. and Dhar, U. Box Myrtle (Myrica esculenta, Kaiphal) A promising underexploited tree crop of Himalaya. Himavikas occasional publication, 3rd ed, GB Pant Institute of Himalayan Environment and Development, Almora, pp.33 (1994)

2. Bhat, D.M., Naik, M.B., Patagar, S.G., Hegde, G.T., Kanade, Y.G., Hegde, G.N. Shastri, C.M., Shetti D.M. and Furtado R.M. Forest dynamics in tropical rain forests of Uttara kannada district in Western Ghats, India. Current Science, 79: 975-985 (2000)

3. Nainwal, P. and Kalra, K. Study on the Wound Activity Potential on the Aqueous Extract of the Bark of Myrica esculenta Buch \& Ham. International Journal of Pharmaceutical and Clinical Research, 1(2): 85-87 (2009)

4. Kapkoti, B., Adhikari, B., Lodhiyal, N. and Lodhiyal, L.S. Structure and Diversity of Sal forests in Government and Community management systems in Kumaun region of Central Himalaya. Current World Environment, 11(1): 126-132 (2016)

5. Singh, J.S. and Singh, S.P. Forests of Himalaya: Structure, functioning and impact of Man. Gyanodaya Prakashan, Nainital, India (1992)

6. Saxena, A.K. and Singh, J.S. Quantitative profile structure of certain forest in the Kumaun Himalaya: Proceeding of the Indian Academy of Sciences, 91: 529-49 (1982)

7. Misra, R. Ecology Work Book.Oxford and IBH Publishing Company, Calcutta pp.244 (1968)

8. Shannon, C.E. and Wiener, W. The mathematical theory of Communication. University Illinois Press, Urbana, U.S.A. pp117 (1963)

9. Simpson, E. H. Measurement of diversity. Nature, 163: 688-692 (1949)

10. Shankar, U. A case study of high tree diversity in a Sal (Shorea robusta) dominated lowland forest of Eastern Himalaya: Floristic composition, regeneration and conservation. Current Science, 81: 776-786 (2001)

11. Rawat, Y.S. and Singh, J.S. Structure and function of Oak forest in Central Himalaya. I. dry matter dynamics. Annals of Botany, 62 : 397-41(1988)

12. Adhikari, B.S., Rawat Y.S. and Sing S.P. Structure and function of high altitude forests of Central Himalaya I. Dry matter dynamics. Annals of Botany, 72: 237-348 (1995)

13. Magnussen, S. and Reed, D. Modelling for Estimation and Monitoring. FAO- IUFRO, (2004)

14. Saxena, A.K. and Singh, J.S. Tree population structure of certain Himalayan forest associations and implications concerning their future composition. Vegetatio, 58: 61-69 (1984)

15. Kumar, A. and Ram, J. Anthropogenic disturbances and plant biodiversity in forests of Uttarakhand, Central Himalaya. Biodiversity and Conservation, 14: 300-331 (2005)

16. Sah, P. Plant species diversity assessment in undisturbed and disturbed oak forestsof Central Himalaya, Ph.D. Thesis, Kumaun University, Nainital (2007)

17. Lodhiyal, N. and Lodhiyal, L.S. Tree layer composition and carbon content of Oak and Pine in Lohaghat forest of Kumaun Himalaya. Journal of plant development Science. 4(1): 55-62. (2012)

18. Lodhiyal, N., Dhek, S., Lodhiyal, L. S., Bhakuni, N. and Kapkoti, B. Species diversity and regeneration of Tilonj Oak (Quercus floribunda Lindl.) dominated forest of Nainital in Kumaun Himalaya. International Journal of Biodiversity and Conservation, 7(1): 21-27 (2015)

19. Singh, J.S. and Singh, S.P. Forest vegetation 
of the Himalaya. Botanical Review , 52: 80192 (1987)

20. Ralhan, P.K., Saxena, A.K. and Singh, J. S. Analysis of forest vegetation at and around Nainital in Kumaun Himalaya. Proceeding of Indian National Science Academy, 48 B: 122-138 (1982)

21. Raturi, G.P. Forest community structure along an altitudinal gradient of district Rudraprayg of Garhwal Himalaya, India. Ecology, 2(3): 76-84 (2012)

22. Good, N.F. and Good, R.E. Population dynamics of tree seedlings and saplings in mature Eastern hardwood forest. Bulletin of Torrey Botanical Club, 99: 172-178 (1972)

23. Dhaulkhandi, M., Dobhal, A., Bhatt, S. and Kumar, M. Community structure and regeneration potaintial of Natural Forest site in Gangotri, India. Journal of Basic and Applied Science, 4: 49-52 (2008)

24. Sahu, S. Sahu, C.R. Yadav, A. Rathod, P. Chaturvedi, S. and Tripathi, R. Review on Myrica ensculata; A popular plant of Himalayan region. Journal of Chemical and Pharmaceutical Science, 6: 93-97 (2013). 